\title{
TAXONOMIC DIVERSITY OF FERNS OF TWO RECREATIONAL FORESTS IN KEDAH, MALAYSIA
}

\author{
Zakaria Bin Rahmad ${ }^{1 \mathrm{a}}$ and Gbenga Festus Akomolafe $\mathrm{e}^{2 *}$
}

aSchool of Biological Sciences, Universiti Sains Malaysia, 11800, Pulau Pinang, MALAYSIA. Email: rahmadz@usm.my'i gfakomolafe@yahoo.com²

*Corresponding author: gfakomolafe@yahoo.com

Received: 20 ${ }^{\text {th }}$ Jan $2019 \quad$ Accepted: 23 ${ }^{\text {rd }}$ Aug 2019

Published: $31^{\text {st }}$ Dec 2019

DOI: https://doi.org/10.22452/mjs.vol38no3.1

\begin{abstract}
The paucity of published data on the diversity and richness of ferns in Bukit Hijau recreational forest and Sungai Sedim forest in Kedah, Malaysia, prompted this study. This was to provide a baseline checklist of the ferns in these two forests. We conducted a field survey covering a distance of about $4000 \mathrm{~m}$ from the entrance of the forests. Preferential non-random sampling was employed, whereby all the encountered ferns were collected and identified. The incidence data were used to estimate the species richness and diversity indices through rarefaction and extrapolation analysis. It was observed that Bukit Hijau forest was more abundant in fern species and more diverse than Sungai Sedim forest. A total of 44 ferns were documented at Bukit Hijau forest while 28 were observed at Sungai Sedim forest with the family Polypodiaceae dominating the two forests. Thirteen ferns were observed to be similar in the two forests, thereby giving a Sorensen similarity index of $36.11 \%$. Data on the IUCN conservation status of 56 ferns out of 58 were lacking. Suitable microhabitat conditions such as abundant moisture and low light intensity may be responsible for the higher richness of ferns at Bukit Hijau forest than Sungai Sedim forest. Future study is needed in relating the presence of the ferns with environmental gradients to better understand the conditions enhancing the ferns of these two forests.
\end{abstract}

Keywords: Bukit Hijau, Ferns, Kedah, Polypodiaceae, Sungai Sedim

\section{INTRODUCTION}

Ferns (pteridophytes), in general, have been described as constituting an indispensable part of the natural habitats, flora, and biodiversity of tropical forests (Haque, Khan, Uddin, \& Rahim, 2016). They usually form substantial biomass of some forests in the tropical and subtropical regions of the world (Yusuf, 2010). Besides, ferns have become beneficial to humankind in so many ways, including as medicines, ornamentals, and food (Singh, Saha, \& Maheshwari, 1989; Sarker \& Hossain, 2009; Uddin, Rahman, Uddin, \& Pasha, 2008). Ferns can adapt to varying types of environment as a result of evolutionary processes (Mehltreter, Walker, \& Sharpe, 2010). Despite their adaptation to different types of habitats, their survival has been threatened by a lot of ecosystem disturbances (Dixit, 2000). About 1165 species of ferns have been collected in the Malaysian tropical rain forests out of the 4400 fern species reported in South East Asia (Parris \& Latiff, 1997). Out of this 1165 Malaysian fern species, 750 have been reported in Sabah, 615 in Sabah, and the remaining 647 in Peninsular Malaysia (Bedawi, Go, \& Mustafa, 2009).

The increasing level of urbanization globally has affected the 
native biodiversity and consequently reduced the areas reserved for primary and secondary forests $(\mathrm{Ng}$, Corlett, \& Tan, 2011). This has many implications in the conservation status of many ferns because many shade-loving ferns are more prone to such changes (Anthony, Majuakim, \& Suleiman, 2016). As the secondary forests are formed, many microclimatic conditions necessary for the growth and survival of ferns are drastically altered, thereby giving room for more light-loving plants to colonize the forest. The lack of accurate and adequate records on diversity, distribution, and abundance of ferns as a result of the changes in the natural environment could not allow us to have estimates on the rate of extinction of many ferns across the world (Davison, $\mathrm{Ng}, \&$ Ho, 2008).

Despite the extensive collection of ferns across Peninsular Malaysia by many pteridologists over the years, there has not been any reported literature on the composition and diversity of fern species at the Bukit Hijau and Sungai Sedim recreational forests in Kedah, Malaysia. In trying to bridge this botanical gap, this study hence aimed at establishing a preliminary checklist of ferns diversity in these recreational forests and then produces a first record of the identified fern species in the study areas.

\section{METHODOLOGY}

\subsection{Study Area}

The study was carried out at two recreational forests in Kedah, Malaysia, which were Bukit Hijau recreational forest $\left(5^{\circ} 30^{\prime} 09.90^{\prime \prime} \mathrm{N}\right.$ and $\left.100^{\circ} 46^{\prime} 31.86^{\prime \prime} \mathrm{E}\right)$, located at $42 \mathrm{~km}$ from Baling town in Kedah, Malaysia and Sungai Sedim recreational forest $\left(5^{\circ} 24^{\prime} 47.88^{\prime \prime} \mathrm{N}\right.$ and $\left.100^{\circ} 4651.66^{\prime \prime} \mathrm{E}\right)$, located in Kulim, Kedah,
Malaysia. Bukit Hijau recreational forest was established in 1959, and it has served several purposes, such as campsites, picnics, eco-tourism, and educational and research activities. The Bukit Hijau recreational forest has also served as the habitat to wildlife, including tigers, elephants, tapirs, deer, birds, monkeys, and squirrels (Hussein, 2014). The vegetation in this forest can be categorized into lowland and slightly hill dipterocarp vegetation housing a waterfall. The forest is elevated at $150-300 \mathrm{~m}$ above the sea level. However, Sungai Sedim recreational forest, having an area of about 36,979 hectares was classified as a permanent forest reserve in 1937. Despite being a forest reserve, it also provides many recreational purposes, such as housing one of the longest canopy walkway of 925 meters long at 26 meters above ground level. These two forests can be described as comprising primary and secondary forests due to the little human disturbances (Gibson et al., 2011).

\subsection{Survey Method}

We employed a non-random preferential survey method whereby all the fern species that were encountered in the forests beginning from the entrance to a distance of about $4000 \mathrm{~m}$ were collected, identified, and documented (Akinsoji et al., 2016). The survey was conducted in November and December 2018. The incidence of each fern species documentation was conducted for each of the forests. Epiphytic ferns that are beyond the reach of the researcher were viewed using a field binocular. The conservation status of these ferns was assessed from the IUCN red list website (www.iucnredlist.org), and each species were identified using a taxonomic flora (Piggott, 1988). The voucher specimens were deposited in the Universiti Sains Malaysia herbarium. 


\subsection{Statistical Analysis}

We used an incidence-based nonasymptotic rarefaction and extrapolation analysis to evaluate the ferns species richness, Shannon index, and Simpson index of the two recreational forests. This was performed with the use of iNEXT online software (Chao, Ma, \& Hsieh, 2016). Significant differences in the diversity indices between the two forests were determined using confidence intervals. Sorenson similarity index was calculated to determine the similarity in ferns species between the two sampling locations.

$$
S c=\frac{2 W}{a+b} \times 100
$$

Where, $S c$ is the similarity coefficient, $W$ is the species occurring in both forests under consideration, $a$ represents the number of species found in Bukit Hijau forest, and $b$ is the number of species occurring in Sungai Sedim forest.

\section{RESULTS AND DISCUSSION}

A total of 43 fern species were encountered at Bukit Hijau recreational forest, while 28 species were recorded at Sungai Sedim forest (Table 1). Thirteen ferns including Acrosticum aureum, Asplenium batuense, Bolbitis virens, Davalia denticulata, Drynaria rigidula, Gleichenia truncata, Hymenophyllum acanthoides, Lindsaea lucida, Nephrolepis biserrata, Phymatosorus nigrescens, Pteris venulosa, Pteris vittata, and Pyrrosia lanceolata were found to be familiar to both forests. This gives rise to a similarity coefficient of $36.11 \%$ between the two forests. With regards to all the similar species between the two forests, 58 fern species belonging to 33 genera and 19 families were observed (Table 1). The family Polypodiaceae could be regarded as the richest in the two forests having a total of 12 ferns species, while Schizaeaceae, Dennstaedtiaceae, Hemionitidaceae, Hypolepidaceae, Grammitidaceae, and Vittariaceae are the least rich families having only one species each. Family Polypodiaceae had nine species in Bukit Hijau forest and six species in Sungai Sedim forest (Table 2). This low total number of fern species recorded in this study could be due to the relatively short period of the survey conducted. A more substantial number of fern species can be encountered and documented provided an extensive survey was carried out (Suis, Anthony, Andi, \& Suleiman, 2016).

Out of the 58 ferns observed, only two species, i.e. Dicranopteris linearis and $P$. vittata were assessed by IUCN and categorized as the least concern/stable species (Table 3). The remaining 56 ferns have not been assessed by IUCN. This lack of global data on the assessment of the conservation status of these ferns is a clear indication of their neglect by environmentalists and conservationists. It is, therefore, necessary for the Malaysia government to have a comprehensive national red list assessment of all plants, including ferns, just like Singapore (Davison et al., 2008). The focus so far has been on the assessment of higher plants and animals in Peninsular Malaysia (Chua, Suhaida, Hamidah, \& Saw, 2010; Chen, 2004; Department of Wildlife and National Parks [DWNP], 2010). Based on the rarefaction and extrapolation analysis of fern species richness and diversity indices of these two forests, Bukit Hijau forest is richer and more diverse than Sungai Sedim forest (Figure 2). The confidence intervals clearly showed that the differences in the species richness, Shannon diversity, and Simpson diversity indices between the two forests are highly significant.

The higher fern species richness and diversity observed at Bukit Hijau forest than Sungai Sedim could be due to 
high shade, high humidity, and low light intensity, which characterize tropical primary forests (Anthony et al., 2016). Most of the ferns are shade- and high moisture-loving plants and consequently will prefer more shady forest to open forest (Othman, Latiff, Tukiman, \& Hashim, 2015). However, our observation is subjective, as there was no quantitative measurement of these microclimatic conditions. Other studies have also highlighted the relative importance of these microclimatic conditions on the occurrence and distribution of ferns species in tropical forests (Korner, 2000; Large \& Braggins, 2004). Also, a higher Simpson index of the Bukit Hijau forest indicated that it is dominated by several fern species with higher incidences across the forest. The lushness of ferns in a forest could be an indicator of the stability and quality of such forest (Beukema \& van Noordwijk, 2004; Othman et al., 2015). Moreover, the presence of ferns could also be used to assess the suitability of forests as habitats for other plant functional groups (Duque et al., 2005; Large \& Braggins, 2004). Therefore, this indicates that the two forests studied are healthy and suitable habitats for the survival and conservation of other plant species. Besides rainfall, the waterfalls, which run through the two forests could have been additional sources of water to the ferns, as it has already been established that ferns richness are triggered by high moisture availability (Barrington, 1993). It is also possible that the richness and diversity of ferns observed at these two forests could be mostly influenced by other factors such as elevation and light intensity as reported by earlier researches, although our study did not focus on the diversity of ferns along environmental gradients (Nor, 2001; Hemp, 2002).

\section{CONCLUSION}

Despite the short period of the survey, this preliminary study provided a view of the diverse nature of the Bukit Hijau and Sungai Sedim forests in terms of fern species. This study has also shown that these two forests, specifically Bukit Hijau recreational forest, has a high diversity of fern species. Therefore, more studies covering a more extended period and areas are needed to further unveil the richness of these two forests in the future.

Table 1. Checklist of fern species at the two recreational forests

\begin{tabular}{|c|c|c|c|c|}
\hline $\mathrm{S} / \mathrm{N}$ & Species Name & Family Name & $\begin{array}{c}\text { Bukit Hijau } \\
\text { Forest } \\
\text { Presence / } \\
\text { Absence }\end{array}$ & $\begin{array}{c}\text { Sungai Sedim } \\
\text { Forest } \\
\text { Presence / } \\
\text { Absence }\end{array}$ \\
\hline 1 & Acrosticum aureum L. & Pteridaceae & $\sqrt{ }$ & $\sqrt{ }$ \\
\hline 2 & $\begin{array}{l}\text { Angiopteris angustifolia } \\
\text { Presl }\end{array}$ & Marattiaceae & $\sqrt{ }$ & $X$ \\
\hline 3 & $\begin{array}{l}\text { Angiopteris evecta (Forst.) } \\
\text { Hoffm. }\end{array}$ & Marattiaceae & $\sqrt{ }$ & $X$ \\
\hline 4 & $\begin{array}{l}\text { Asplenium batuense } \\
\text { Alderw. }\end{array}$ & Aspleniaceae & $\sqrt{ }$ & $\sqrt{ }$ \\
\hline 5 & Asplenium nidus L. & Aspleniaceae & $\sqrt{ }$ & $\mathrm{X}$ \\
\hline 6 & $\begin{array}{l}\text { Asplenium scortechinii } \\
\text { Bedd. }\end{array}$ & Aspleniaceae & $\sqrt{ }$ & $X$ \\
\hline 7 & $\begin{array}{l}\text { Bolbitis heteroclita (Presl) } \\
\text { Ching }\end{array}$ & Lomariopsidaceae & $\mathrm{X}$ & $\sqrt{ }$ \\
\hline
\end{tabular}


8 Bolbitis sinuatea (Presl) Lomariopsidaceae Hennipman

9 Bolbitis virens (Wall. Ex Lomariopsidaceae Hook. \& Grev.) Schott

10 Cibotium barometz (L.) Cyatheaceae J.Sm.

11 Cyathea contaminans Cyatheaceae (Hook.) Copel

12 Cyathea moluccana R. Br. Cyatheaceae

13 Cyclopeltis crenata (Fee) Aspidiaceae C. Chr.

14 Cyclosorus subpubescens Thelypteridaceae (B1.) Ching

15 Davalia denticulata Davalliaceae (Burm.) Mett.

16 Davalia solida (Forst.) Sw. Davalliaceae

17 Dicranopteris linearis Gleicheniaceae (Burm.) Underwood

18 Drynaria quercifolia (L.) Polypodiaceae $\quad \sqrt{ }$ X J.Sm.

19 Drynaria rigidula (Sw.) Polypodiaceae Bedd. (Desv.) Moore

21 Drymoglossum piloselloides (L.) Presl

22 Gleichenia truncata Gleicheniaceae (Willd.) Spreng.

23 Goniophlebium verrucosum (Hook.) J.Sm.

24 Hymenophyllum acanthoides (Bosch) Rosenst.

25 Hymenophyllum productum Kunze

26 Hymenophyllum serrulatum (Presl) C.Chr.

27 Lepisorus longifolius (B1.) Polypodiaceae Holtt.

28 Lindsaea lucida Bl. Lindsaeaceae

29 Lindsaea napaea Alderw. Lindsaeaceae

30 Lygodium longifolium Schizaeaceae (Willd.) Sw.

31 Nephrolepis acutifolia Nephrolepidaceae (Desv.) Christ

32 Nephrolepis biserrata Nephrolepidaceae (Sw.) Schott

33 Nephrolepis dicksonioides Nephrolepidaceae Christ

34 Nephrolepis radicans Nephrolepidaceae 


\begin{tabular}{|c|c|c|c|c|}
\hline & (Burm.) Kuhn & & & \\
\hline 35 & $\begin{array}{l}\text { Nephrolepis tuberosa } \\
\text { (Bory) Presl }\end{array}$ & Nephrolepidaceae & $\sqrt{ }$ & $\mathrm{X}$ \\
\hline 36 & $\begin{array}{l}\text { Orthiopteris kingii (Bedd.) } \\
\text { Holtt. }\end{array}$ & Dennstaedtiaceae & $\sqrt{ }$ & $X$ \\
\hline 37 & $\begin{array}{l}\text { Photinopteris speciosa } \\
\text { (B1.) Presl }\end{array}$ & Polypodiaceae & $X$ & $\sqrt{ }$ \\
\hline 38 & $\begin{array}{l}\text { Phymatosorus nigrescens } \\
\text { (B1.) Pichi Serm. }\end{array}$ & Polypodiaceae & $\sqrt{ }$ & $\sqrt{ }$ \\
\hline 39 & $\begin{array}{l}\text { Pityrogramma } \\
\text { calomenalos }(\mathrm{L} .) \text { Link }\end{array}$ & Hemionitidaceae & $\sqrt{ }$ & $\mathrm{X}$ \\
\hline 40 & $\begin{array}{l}\text { Platycerium coronatum } \\
\text { (Koenig) Desv. }\end{array}$ & Polypodiaceae & $\sqrt{ }$ & $\mathrm{X}$ \\
\hline 41 & $\begin{array}{l}\text { Platycerium holttumii } \\
\text { Henn. \& Jonch. }\end{array}$ & Polypodiaceae & $\mathrm{X}$ & $\sqrt{ }$ \\
\hline 42 & $\begin{array}{l}\text { Pneumatopteris truncata } \\
\text { (Poir.) Holtt. }\end{array}$ & Thelypteridaceae & $\sqrt{ }$ & $\mathrm{X}$ \\
\hline 43 & $\begin{array}{l}\text { Pteris longipinnula Wall. } \\
\text { ex Agardh }\end{array}$ & Pteridaceae & $X$ & $\sqrt{ }$ \\
\hline 44 & Pteris semipinnata L. & Pteridaceae & $\sqrt{ }$ & $X$ \\
\hline 45 & Pteris venulosa $\mathrm{B} 1$. & Pteridaceae & $\sqrt{ }$ & $\sqrt{ }$ \\
\hline 46 & Pteris vittata $\mathrm{L}$. & Pteridaceae & $\sqrt{ }$ & $\sqrt{ }$ \\
\hline 47 & $\begin{array}{l}\text { Pteridium caudatum (L.) } \\
\text { Maxon }\end{array}$ & Hypolepidaceae & $\sqrt{ }$ & $X$ \\
\hline 48 & $\begin{array}{l}\text { Pyrrosia lanceolata (L.) } \\
\text { Farwell }\end{array}$ & Polypodiaceae & $\sqrt{ }$ & $\sqrt{ }$ \\
\hline 49 & $\begin{array}{l}\text { Pyrrosia varia (Kaulf.) } \\
\text { Farwell }\end{array}$ & Polypodiaceae & $X$ & $\sqrt{ }$ \\
\hline 50 & $\begin{array}{l}\text { Scleroglossum minus (Fee) } \\
\text { C.Chr. }\end{array}$ & Grammitidaceae & $\sqrt{ }$ & $X$ \\
\hline 51 & $\begin{array}{l}\text { Tectaria barberi (Hook.) } \\
\text { Copel }\end{array}$ & Aspidiaceae & $\sqrt{ }$ & $\mathrm{X}$ \\
\hline 52 & Tectaria crenata Cav. & Aspidiaceae & $\sqrt{ }$ & $X$ \\
\hline 53 & $\begin{array}{l}\text { Tectaria gradidentata } \\
\text { (Cesati) Holtt. }\end{array}$ & Aspidiaceae & $X$ & $\sqrt{ }$ \\
\hline 54 & $\begin{array}{l}\text { Tectaria singaporeana } \\
\text { (Wall.) Ching }\end{array}$ & Aspidiaceae & $\sqrt{ }$ & $\sqrt{ }$ \\
\hline 55 & $\begin{array}{l}\text { Thelipteris } \\
\text { (Copel.) Holtt. }\end{array}$ & Thelypteridaceae & $\sqrt{ }$ & $\mathrm{X}$ \\
\hline 56 & $\begin{array}{l}\text { Thelipteris viscosa (J.Sm.) } \\
\text { Ching }\end{array}$ & Thelypteridaceae & $\sqrt{ }$ & $\mathrm{X}$ \\
\hline 57 & $\begin{array}{l}\text { Trichomanes } \\
\text { Forster }\end{array}$ & Hymenophyllaceae & $\sqrt{ }$ & $X$ \\
\hline 58 & Vittaria elongata $\mathrm{Sw}$. & Vittariaceae & $X$ & $\sqrt{ }$ \\
\hline
\end{tabular}

KEY: $\sqrt{ }$ means present, $\mathrm{X}$ means absent 
Table 2. Checklist of families with respective numbers of general and species

\begin{tabular}{llcccc}
\hline S/N & FAMILY & \multicolumn{2}{c}{ BUKIT HIJAU FOREST } & \multicolumn{2}{c}{ SUNGAI SEDIM FOREST } \\
\hline & & $\begin{array}{c}\text { Number of } \\
\text { Genera }\end{array}$ & $\begin{array}{c}\text { Number of } \\
\text { Species }\end{array}$ & $\begin{array}{c}\text { Number of } \\
\text { Genera }\end{array}$ & $\begin{array}{c}\text { Number of } \\
\text { Species }\end{array}$ \\
\cline { 3 - 6 } 1 & Aspidiaceae & 2 & 4 & 1 & 2 \\
2 & Aspleniaceae & 1 & 3 & 1 & 1 \\
3 & Cyatheaceae & 1 & 2 & 1 & 1 \\
4 & Davalliaceae & 1 & 1 & 1 & 2 \\
5 & Dennstaedtiaceae & 1 & 1 & 0 & 0 \\
6 & Gleicheniaceae & 1 & 1 & 2 & 2 \\
7 & Grammitidaceae & 1 & 1 & 0 & 0 \\
8 & Hemionitidaceae & 1 & 1 & 0 & 0 \\
9 & Hymenophyllaceae & 1 & 2 & 1 & 0 \\
10 & Hypolepidaceae & 1 & 1 & 0 & 1 \\
11 & Lindsaeaceae & 1 & 2 & 1 & 0 \\
12 & Lomariopsidaceae & 1 & 1 & 0 & 2 \\
13 & Marattiaceae & 1 & 2 & 1 & 6 \\
14 & Nephrolepidaceae & 1 & 4 & 5 & 4 \\
15 & Polypodiaceae & 7 & 9 & 2 & 0 \\
16 & Pteridaceae & 2 & 4 & 0 & 1 \\
17 & Schizaeaceae & 1 & 1 & 1 & 1 \\
18 & Thelypteridaceae & 2 & 3 & 1 & 0 \\
19 & Vittariaceae & 0 & 0 & & 2 \\
\hline
\end{tabular}

Table 3. IUCN conservation status of ferns in the recreational forests

\begin{tabular}{lcc}
\hline \multicolumn{1}{c}{ IUCN Red List Status } & $\begin{array}{c}\text { Number of } \\
\text { species }\end{array}$ & Name of Species \\
\hline Extinct (EX) & 0 & Nil \\
Extinct in the Wild (EW) & 0 & Nil \\
Regionally Extinct (RE) & 0 & Nil \\
Critically Endangered & 0 & Nil \\
(CR) & 0 & Nil \\
Endangered (EN) & 0 & Nil \\
Vulnerable (VU) & 0 & Dicranopteris linearis, Pteris vittata \\
Near Threatened (NT) & 2 & Nil \\
Least Concern (LC) & 0 & Others \\
Data Deficient (DD) & 56 & \\
Not Evaluated (NE) & & \\
\hline
\end{tabular}




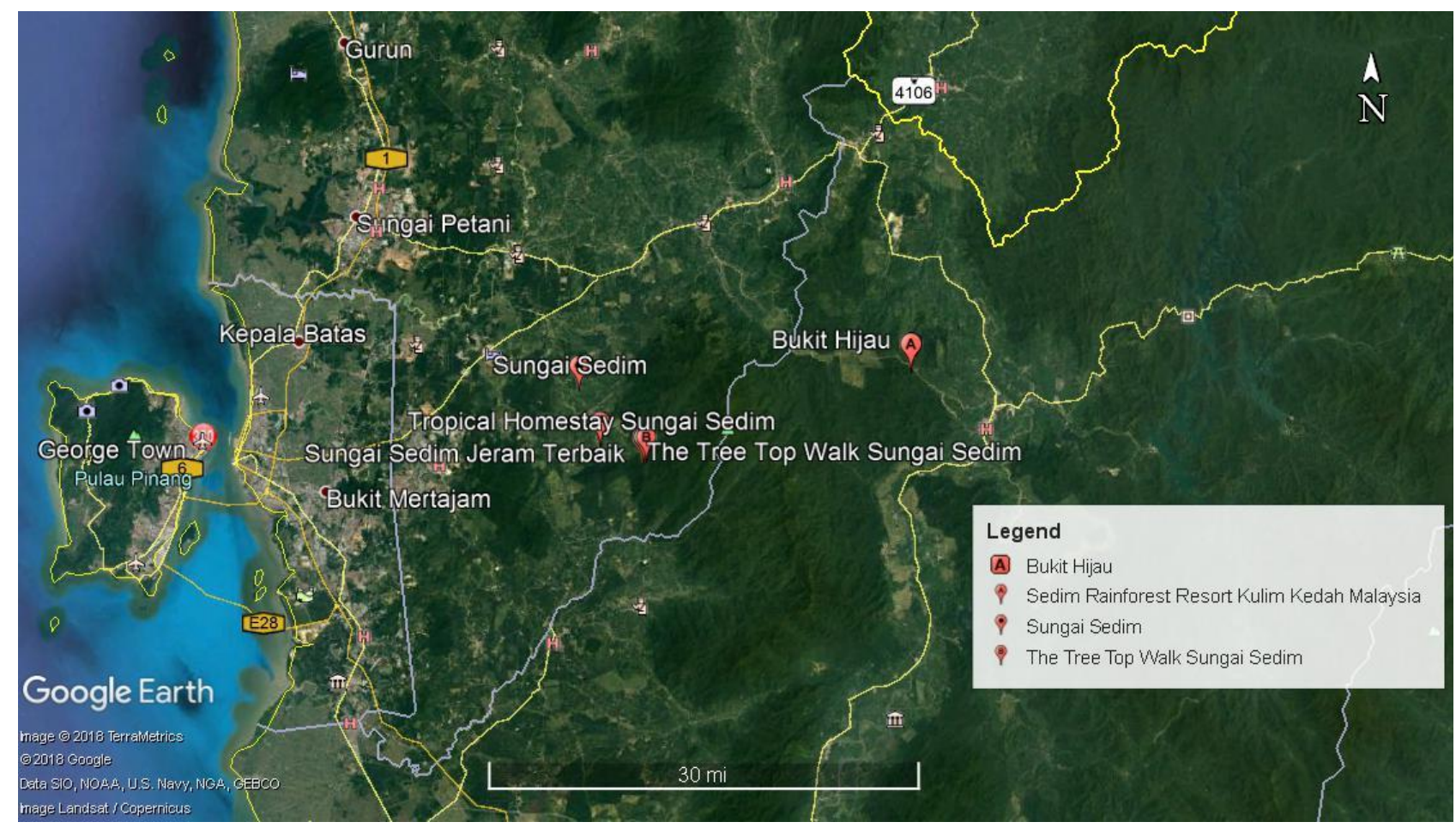

Figure 1. Google earth map of the study sites
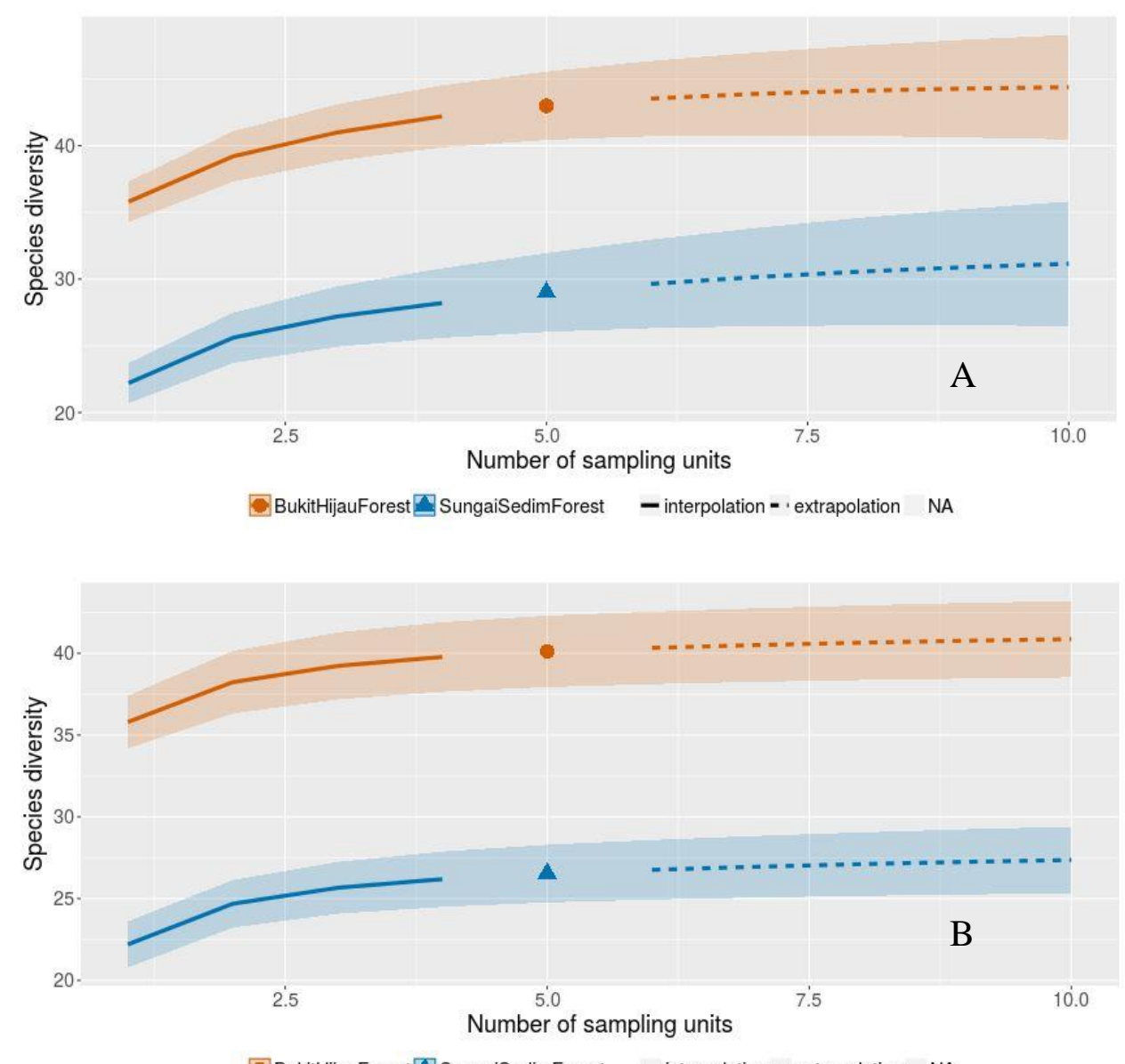

BukitHijauForest $\triangle$ SungaiSedimForest - interpolation -'extrapolation NA 


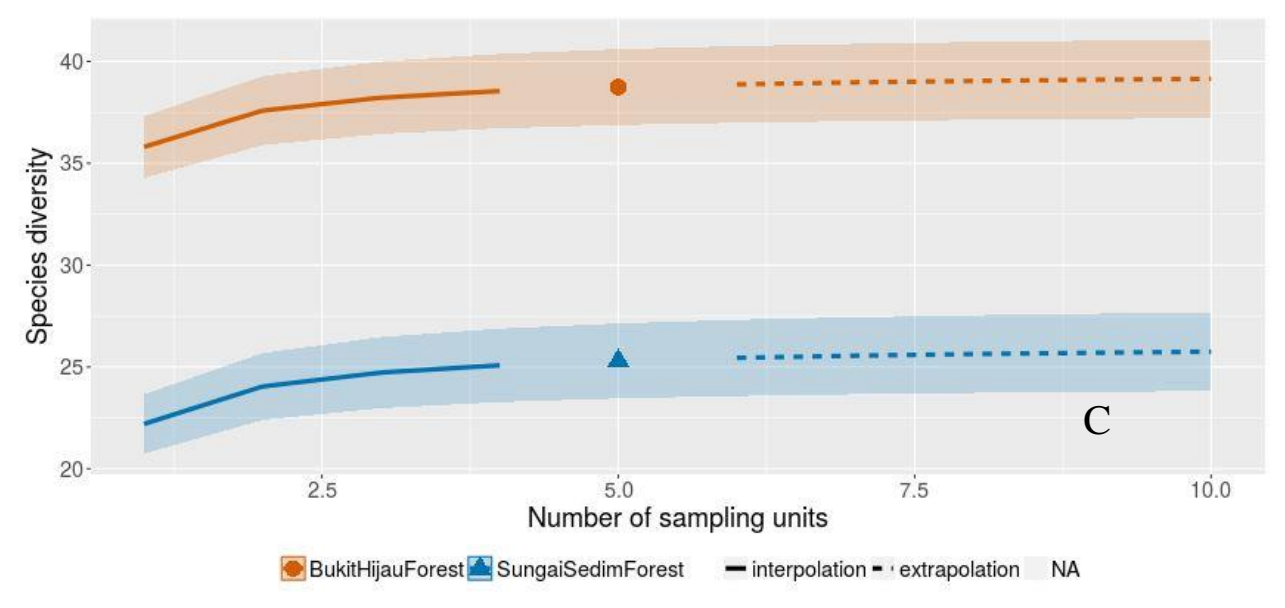

Figure 2. Incidence based rarefaction and extrapolation curves for (A) Species richness (B) Shannon index (C) Simpson index. Solid lines represent rarefaction curves while dashed lines represent extrapolation curves. Each shape stands for the estimated index. The shadow of each curve represents the confidence interval.

\section{ACKNOWLEDGEMENTS}

We hereby acknowledge the financial supports from Universiti Sains Malaysia through these research grants R304/PBIOLOGI/650863/K146 and 1001/PBIOLOGI/811330.

\section{REFERENCES}

Akinsoji, A., Agboola, O., Adeonipekun, P., Oyebanji, O., Adeniyi, T., \& Ajibode, M. (2016). Occurrence and distribution of Pteridophytes in parts of Lagos and Osun states. Ife Journal of Science, 18(2), 447453.

Anthony, F., Majuakim, L., \& Suleiman, M. (2016). Fern diversity in primary and secondary forests of Danum Valley and Ulu Segama Forest Complex, Lahad Datu, Sabah. Transactions on Science and Technology, 3(1-2), 77-84.

Barrington, D. S. (1993). Ecological and historical factors in fern biogeography. Journal of Biogeography, 20, 275-279.
Bedawi, S. H. A., Go, R., \& Mustafa, M. (2009). New records of terrestrial pteridophytes in Genting Highlands, Pahang, Malaysia. Pertanika Journal of Tropical Agricultural Science, 32(2), 169174.

Beukema, H., \& van Noordwijk, M. (2004). Terrestrial pteridophytes as indicators of a forest-like environment in rubber production systems in the lowlands of Jambi, Sumatra. Agriculture, Ecosystems \& Environment, 104(1), 63-73.

Chao, A., Ma, K. H., \& Hsieh, T. C. (2016). User's guide for iNEXT Online: Software for interpolation and extrapolation of species diversity. DOI: 10.13140/RG.2.2.25777.79200

Chen, H. K. (2004). A Malaysian assessment of the world list of threatened trees. Selangor, Malaysia: TRAFFIC Southeast Asia.

Chua, L., Suhaida, M., Hamidah, M., \& Saw, L. (2010). Malaysia plant red 
list: Peninsular Malaysian Dipterocarpaceae (p 210). Kuala Lumpur, Malaysia: Forest Research Institute Malaysia.

Davison, G. W. H., Ng, P. K. L., \& Ho, H. C. (2008). The Singapore Red Data Book: Threatened plants \& animals of Singapore. Singapore: Nature Society.

Dixit, R. D. (2000). Conspectus of Pteridophytic diversity in India. Indian Fern Journal, 17(1-2), 7791.

Duque, A. J., Duivenvoorden, J. F., Cavelier, J., Sánchez, M., Polanía, C., \& León, A. (2005). Ferns and Melastomataceae as indicators of vascular plant composition in rain forests of Colombian Amazonia. Plant Ecology, 178(1), 1-13.

Department of Wildlife and National Parks, Peninsular Malaysia (DWNP). (2010). Red list of mammals for Peninsular Malaysia. Kuala Lumpur, Malaysia: Department of Wildlife and National Parks, Peninsular Malaysia (DWNP).

Gibson, L., Lee, T. M., Koh, L. P., Brook, B. W., Gardner, T. A., Barlow, J., ... Sodhi, N. S. (2011). Primary forests are irreplaceable for sustaining tropical biodiversity. Nature, 478(7369), 378-383.

Haque, A. K. M. K., Khan, S. A., Uddin, S. N., \& Rahim, M. A. (2016). Taxonomic checklist of the pteridophytes of Rajkandi Reserve Forest, Moulvibazar, Bangladesh. Jahangirnagar University Journal of Biological Sciences, 5(2), 27-40

Hemp, A. (2002). Ecology of the pteridophytes on the southern slopes of Mt. Kilimanjaro-I. Altitudinal distribution. Plant Ecology, 159(2), 211-239

Hussein, M. K. (2014). Recreational forest landscape development: A strategy for managing forest resources in sustainable manner in Malaysia. Journal of International Scientific Publications: Ecology \& Safety, 8(1314-7234), 31-41.

Korner, C. (2000). Why are there global gradients in species richness? Mountains might hold the answer. Trends in Ecology and Evolution, 15(12), 513-514. DOI: 10.1016/S0169-5347(00)02004-8

Large, M. F., \& Braggins, J. E. (2004). Tree ferns. CSIRO Publishing.

Mehltreter, K., Walker, L. R., \& Sharpe, J. M. (Eds.). (2010). Fern ecology. Cambridge, UK: Cambridge University Press.

Ng, P. K. L., Corlett, R., \& Tan, H. T. W. (2011). Singapore biodiversity: An encyclopedia of the natural environment and sustainable development. Singapore: Editions Didier Millet and Raffles Museum of Biodiversity Research.

Nor, S. M. (2001). Elevational diversity patterns of small mammals on Mount Kinabalu, Sabah, Malaysia. Global Ecology and Biogeography, 10(1), 41-62.

Othman, R., Latiff, N. H. M., Tukiman, I., \& Hashim, K. S. H-Y. (2015). Effects of altitude and microclimate on the distribution of ferns in and urban areas. Jurnal Teknologi (Sciences and Engineering), 77(30), 125-131. 
Parris, B. S., \& Latiff, A. (1997). Towards a pteridophyte flora Malaysia: A provisional checklist of taxa. Malayan Nature Journal, 50(4), 235-280.

Piggott, A. G. (1988). Ferns of Malaysia in colour. Kuala Lumpur, Malaysia: Tropical Press Sdn. Bhd.

Sarker, S. K., \& Hossain, A. B. M. E. (2009). Pteridophytes of greater Mymensingh district of Bangladesh used as vegetables and medicines. Bangladesh Journal of Plant Taxonomy, 16(1), 47-56. DOI: https://doi.org/10.3329/bjpt.v16i1.2 746

Singh, K., Saha, S., \& Maheshwari, J. K. (1989). Ethnomedicinal uses of some ferns among the tribals of
Uttar Pradesh. Indian Fern Journal, 6, 63-67.

Suis, M. A. F., Anthony, F., Andi, M. A. M., \& Suleiman, M. (2016). Additions to the fern flora of the Trusmadi Range, Sabah, Malaysia. Transactions on Science and Technology, 3(2), 313-318.

Uddin, S. B., Rahman, M. A., Uddin, M. G., \& Pasha, M. K. (2008). Ethnobotanical uses of Pteridophyte from Chittagong Hill Tracts of Bangladesh. Nepal Journal of Plant Science, 2(1), 89-93.

Yusuf, U. K. (2010). Ferns of Malaysian rain forest: A journey through the fern world. Selangor, Malaysia: Universiti Putra Malaysia Press. 